\title{
身長の発育パターンの違いによる体力の発達 パターンの検討
}

——青少年期男子について—

$\begin{array}{llll}\text { 渡 } & \text { 辺 } & \text { 隆 } & \text { 嗣 (工学院大学) } \\ \text { 㱜 } & \text { 田 } & \text { 啓 } & \text { 吉 (成踟大学) } \\ \text { 青 } & \text { 柳 } & & \text { 領 (福岡大学) } \\ \text { 松 } & \text { 浦 } & \text { 義 } & \text { 行 (筑波大学) }\end{array}$

（昭和60年 9 月 17 日受付）

\begin{abstract}
A study on developmental patterns of several physical fitness elements in terms of the growth patterns of standing height
\end{abstract}

\author{
Takashi Watanabe ${ }^{1}$ \\ Keikichi Hikita? \\ Osamu Aoyagis \\ Yoshiyuki Matsuura4
}

\begin{abstract}
Developmental patterns of several physical fitness elements in adolescent boys were investigated in reference with growth patterns of standing height. The data used consisted of 5 sets of the 7 -year longitudinal data of 1969, ' 70, ' 71, '72 and '73 enrollments. The mean and standard deviation were determined in each elements with 5 sets of longitudinal data pooled. Then these statistics were used to determine the 10-steps growth and developmental channel for evaluating the individual growth and developmental status in each age. Then, all data were converted to the channel scores using these channels.
\end{abstract}

Results were as follows;

1) By the channel method, growth patterns of standing height were classified into 3 patterns, i.e., early maturing, consistent and late maturing types.

2) Hierarchical cluster analysis was applied to the t-value matrix which was calculated between the patterns of 15 elements. For consistent type, 4 clusters were produced, while 5 clusters each 
were found for early maturing and late maturing types.

3) Developmental pattern curves of each cluster were drawn with the standard scores. With several exceptions, a certain increasing tendency could be observed in consistent and late maturing types. In the early maturing type, most of clusters showed the decreasing tendencies.

4) Between the groups with different growth pattern of standing height, the elements showing the same developmental pattern were not always same, and also each elements did not always show any identical pattern.

(Takashi Watanabe, Keikichi Hikita, Osamu Aoyagi and Yishiyuki Matsuura, "A study on developmental patterns of several physical fitness elements in terms of the growth patterns of standing height", Jap. J. Phys. Educ., 31-3: 213-26, December, 1986)

\section{辕}

最近における青少年の顕著な体位向上傾向の中 で，最す大きな変化を示しているのは思春期の体 力である ${ }^{16), 26)}$.このよ5な現状の中で, 思春期体力 の発達バターンに同する検討は，大変重要な意義 を持っていると考兄られる，従来，思春期体力の 発達に関する検討は，横断的資料によるすのが多 く，発達の変化が著しい思春期体力を検討するに は，個人差を考虑できる縦断的資断を用いること が必要である2!.

発育発達に関する綎断的分析は，相対成長の見 地からの検討, 発育現量値, 発育速度の比較によ るもの，チャンネル法を用いた発育パターンの分 類，さらにはクラスター分析を用いた発達曲線の 分類などの報告がある。

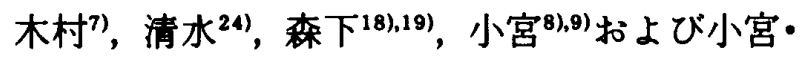
大坂 ${ }^{10)}$ は相対成長の立場から, 乳幼児男女, 小学校 から高等学校に至るまでの男女について，体力の 発達バターンの分類，発育段階区分の検討を行っ ている.

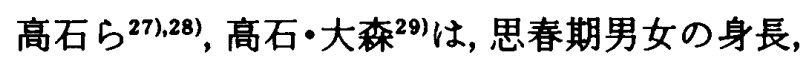
体重の綎断的資料を発育現量值，発育速度から ピーク速度，ピーク年龄を分析している。同様に， 吳・松浦 ${ }^{201,21)}$ 韓国人青少年の発育速度曲線を, 日 本人, 英国人と比交, 考察し, 発育速度变化の考 察から発育加速現象についても検討している。

チャンネル法を用いて発育パターンの分析を 行ったものに, 寺田・保志 ${ }^{30), 31)}$, 木田ら ${ }^{6)}$, 松浦 ${ }^{13)}$ および服部”の報告がある。これらは，乳幼児から
中学 3 年生までの男女と, 大学生男女の形態につ いて検討したもので，各個人の発育曲線が平均値 曲線に対してどのよらな閔係を持つかで，発育八 ターンの分類を行ったものである。

発達曲線の分類については，市村 ${ }^{3) か ゙ ク ラ ス ~}$ ター分析を用いて検討しており，松浦 ${ }^{17}$ もとの必 要性について論じている.

以上の発育発達に関する綎断的分析から, 発育 発達は年龄たけでなく身体属性の影敏をうけなが ら, 各個人によって発育発達のピーク速度, ピー ク年龄が異なることや，発育発達パターンがいく つかに分類されるとともに，身体属性の中でも特 に身長の関与は最も大であると考えられる。

従って, 本研究は中学 1 年生から大学 1 年生す なわち，12歳から18歳に至るまでの男子体力の縦 断的資料について，チャンネル法を用いて各個人 の身長の発育パターンを弁別し，いくつかのグ ループに分類した。このよらにして分類されたグ ループについてクラスター分析を用い，身長の発 育バターンの違いによる青少年男子体力の発達パ ターンの検討を試みた.あのである.

\section{万法}

\section{(1) 标本}

標本は, 1969年 4 月から1973年 4 月までに東京 都武藏野市にある S 学園中学校に入学し, その後 $\mathrm{S}$ 学園高等学校を䅅て S 学園大学に進学した男 子である. 各年度ごとの標本数は, 表 1 に示し だ1!

この資料は䇺密には半緃断的資料（semi-lon- 
Table 1. Sample size.

\begin{tabular}{cccccccc}
\hline $\begin{array}{c}\text { Age } \\
\text { (years old) }\end{array}$ & 12 & 13 & 14 & 15 & 16 & 17 & 18 \\
$\begin{array}{c}\text { Enrollment } \\
\text { year }\end{array}$ & & & & & & & \\
\hline 1969 & 71 & 71 & 73 & 74 & 74 & 74 & 74 \\
\hline 1970 & 61 & 60 & 62 & 64 & 65 & 65 & 64 \\
\hline 1971 & 73 & 74 & 73 & 76 & 76 & 76 & 74 \\
\hline 1972 & 53 & 53 & 53 & 55 & 55 & 55 & 55 \\
\hline 1973 & 32 & 31 & 31 & 31 & 32 & 32 & 32 \\
\hline Total & 290 & 289 & 292 & 300 & 302 & 302 & 299 \\
\hline
\end{tabular}

gitudinal data)であり，そろわない部分は何らか の理由，例えば疾病，傷害等で測定できなかった あのである。ただし，そのような例は数の上から はわずかであり，綎断的資料といっても過言では ないささて，ここで完全な綎断的資料にするため に欠損值をもつ標本を除くことも分考えられる が, 本研究の場合以下の点を考虑して除かないこ とにする.

(1) 本研究の目的は個々の綖断的資料の事例的 変化を検討するのが主ではないので，目的を達成 する上でそれはど問題にならない。

(2) 除く標本の欠損の程度をどのようにするか によって恣意的な判断が加えられる危険がある。

(3) 又, 欠損が1つでもある標本を除くのでは貴 重な情報量を唅てることになり，得られる知見が 偏よる可能性をるつことになる。

\section{（2）湘定项目及ひ測定方法}

本研究で用いられる「体力」とは松浦・中村 ${ }^{12)} の$ い5「基礎運動能力」とほぼ同義語として用いて いる.つまり,「すべての運動の成就にあたって程 度の差こそあれ基碟的な能力として関与する運動 能力の一領域」として捉えている。そして，それ らの下位領域は，(1)体格，(2)敏捷性，(3)基礎運動 技能，(4)静的筋力，(5)瞬発筋力，(6)循環機能，(7) 柔軟性, (8)筋持久力, (9)呼吸・循環系持久力から 構成されると考え，この作業仮説のむとに以下の 研究を進めることにする，よって，これらの下位 領域を測定していると考えられる次の15項目を選 択した。

(1) 体格（1）長育；身長.（2）幅量育；体重,

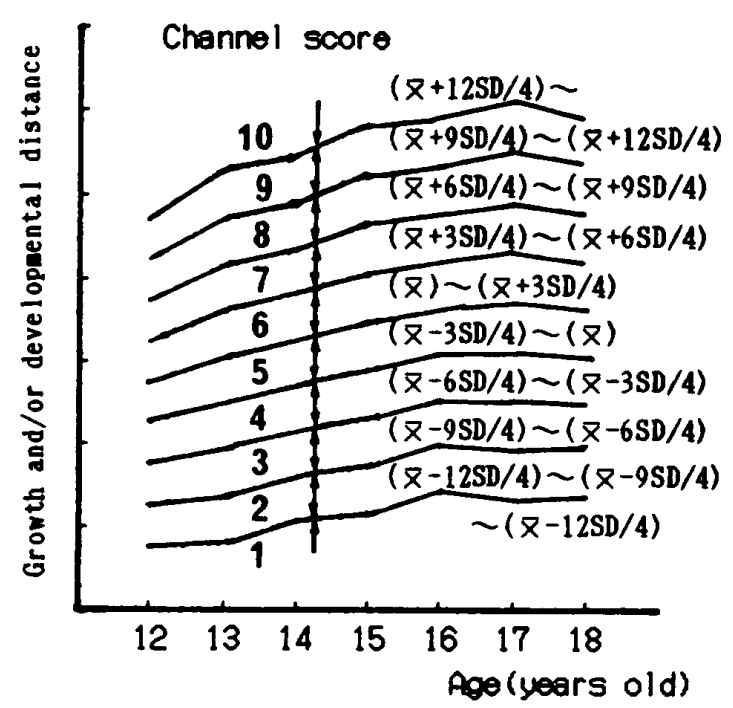

Fig. 1 Ten-point growth and developmental channel.

\section{胸囲}

(2) 敏捷性；反復横跳

（3）基礎運動技能； $50 \mathrm{~m}$ 走，走り幅跳，ハンド ボール投げ

(4) 静的筋力 ; 背筋力, 暒力

(5) 瞬発筋力；垂值跳

(6) 循環機能；踏台昇降

(7) 柔軟性；伏臥上体反らし，立位体前屈

(8) 筋持久力 ; 懸垂

(9) 呼吸・循環系持久力； $1,500 \mathrm{~m}$ 走

選択にあたってはこれらの項目が集団を対象に した場合，短時間で実施でき，特殊な器具を必要 としないという点も考虑した。

測定は，1969年から1979年の各 4 月から 5 月に かけて行われた。身長, 体重, 胸囲については通 常行われている方法 ${ }^{32)} に よ り ，$ 他の測定項目につ いては文部省スポーツテスト実施要項に従った。

\section{（3）統計処理方法}

個人の中学校 1 年生から大学 1 年生に至るまで の 7 年間にわたる15項目の綎断的資料を，各年龄

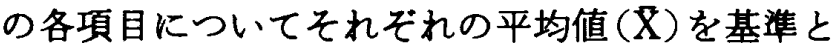
して，3/4位標準偏差 (3/4SD) つ’つの幅を上下に とって，図1に示す10段階評価チャンネル図を構 成した。チャンネル図の得点を操作的に10点法に よって評価するために，漂本の值がほとんど（正 規分布が仮定でさるなら99.74\%)包含されると考 
Table 2. The procedure for classifying the growth and development pattern with channel score.

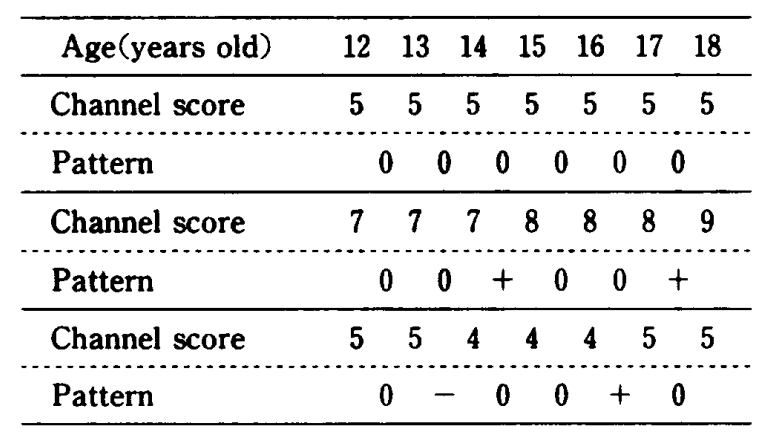

えられる $\overline{\mathrm{X}} \pm 3 \mathrm{SD}^{15}$ を 8 等分（1点と 10 点の部分 を除く）した。その結果，1チャンネル区間の幅 は3/4SDである。このチャンネル図を用いて各項 目の発育発達傾向をチャンネル移動といら観点か ら考察し，表 2 に示す方法で発育発達パターンを 求めた。つまり，表 2 の中でチャンネル点が次の 年龄で増加する場合をプラス $(+)$ ，次の年龄に移 動しても変化しない場合をゼ口 $(0)$ ，次の年秢で 减少する場合はマイナス（一）と考えることにし た.このような加蹂に伴うチャンネル点の変化を 発育発達パターンと考光ることにした。

つぎに，チャンネル法で求めた身長の発育パ ターンを基に，全体をいくつかのグループに分類 した。これらのクループについて，各項目間の発 育発達パターンの差異(距離) を $\mathrm{t}$ 値‘)

$$
\begin{aligned}
& \mathrm{t}_{\mathrm{jk}}=\left|\overline{\mathrm{x}} \bullet_{\mathrm{j}}-\overline{\mathrm{x}} \bullet_{\mathrm{k}}\right| / \mathrm{S}_{\mathrm{jk}} \sqrt{1 / \mathrm{n}_{\mathrm{j}}+1 / \mathrm{n}_{\mathrm{k}}}
\end{aligned}
$$

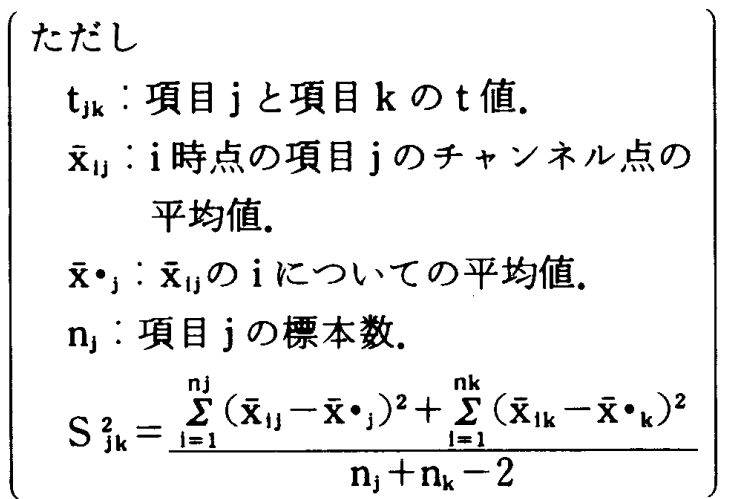

であらわし，ここで得られた $\mathrm{t}$ 行列を資料として 発育発達パターンの階屋的クラスター分析（セン トロイド法) ${ }^{23)}$ を行った。ただし，クラスタリンク の打ち切り基準はデンドロクララムの形態を考虑し た上で，各グループ一率に距離1.0の部分とした。
これにより，各グループごとに同一クラスターに 分類された項目のチャンネル点を標準得点（H 得 点) ${ }^{\text {\#2) }}$

$$
\begin{aligned}
& \mathrm{H}_{1}=50+14\left(\mathrm{x}_{1}-\overline{\mathrm{x}}\right) / \mathrm{SD} \\
& \left(\begin{array}{l}
\text { ただし } \\
\mathrm{H}_{1}: \mathrm{i} \text { 時点の標淮得点 ( } \mathrm{H} \text { 得点). } \\
\mathrm{x}_{1}: \mathrm{i} \text { 時点のチャンネル点. } \\
\overline{\mathrm{x}}: \text { チャンネル点の平均値. } \\
\mathrm{SD}: \text { チャンネル点の標準偏差. }
\end{array}\right)
\end{aligned}
$$

に換算し，その平均值を用いて各々のグループの 発育発達曲線を描いた。

\section{結果と考察}

\section{（1）身長の発育パターンの分類}

本研究で用いられた12歳から18歳までの青少年 男子体力の綎断的資料の平均值，標準偏差は表 3 に示した。この平均値，標準偏差を加龄と共に連 続させた10段階チャンネル法から，先に述べた方 法により求められた各測定項目の発育発達パタ一 ンは，表 4 に示す通りである。表 4 は，各項目ご とに含まれる標本数の多い順に発育発達パターン の種類の一部を示したるのである，その結果，表 中に示された比較的多くの頻度を示したパターン は，形態の 3 項目では执よそ50\%-60\%であり， 運動能力の 12 項目ではおよそ $20 \%$-30\%にすぎな かった。

形態の 3 項目の発育ハターンは, 寺田・保

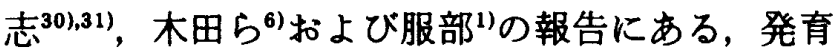

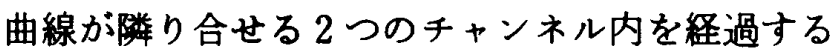
「Consistent type（定増型」に殆んど含まれてし ま5ものである，大学生の形態は，成長につれ相 対的な变動が安定してくるという服部"1の報告 を，本研究の結果す支持するすのである，運動能 力では表 4 が示す通り比教的多くの頻度を示した 発達パターンです $20 \%$ - $30 \%$ であり，その発達パ ターンは個人間での相対的順位関係がかなり変化 することを示唆している，つまり，各個人の発達 過程を一つの傾向としてとらえることが困難であ ることが明らかになった。従って，運動能力の発 達パターンをより細分化してとらえるために，両 
Table 3. Basic statistics of physical fitness.

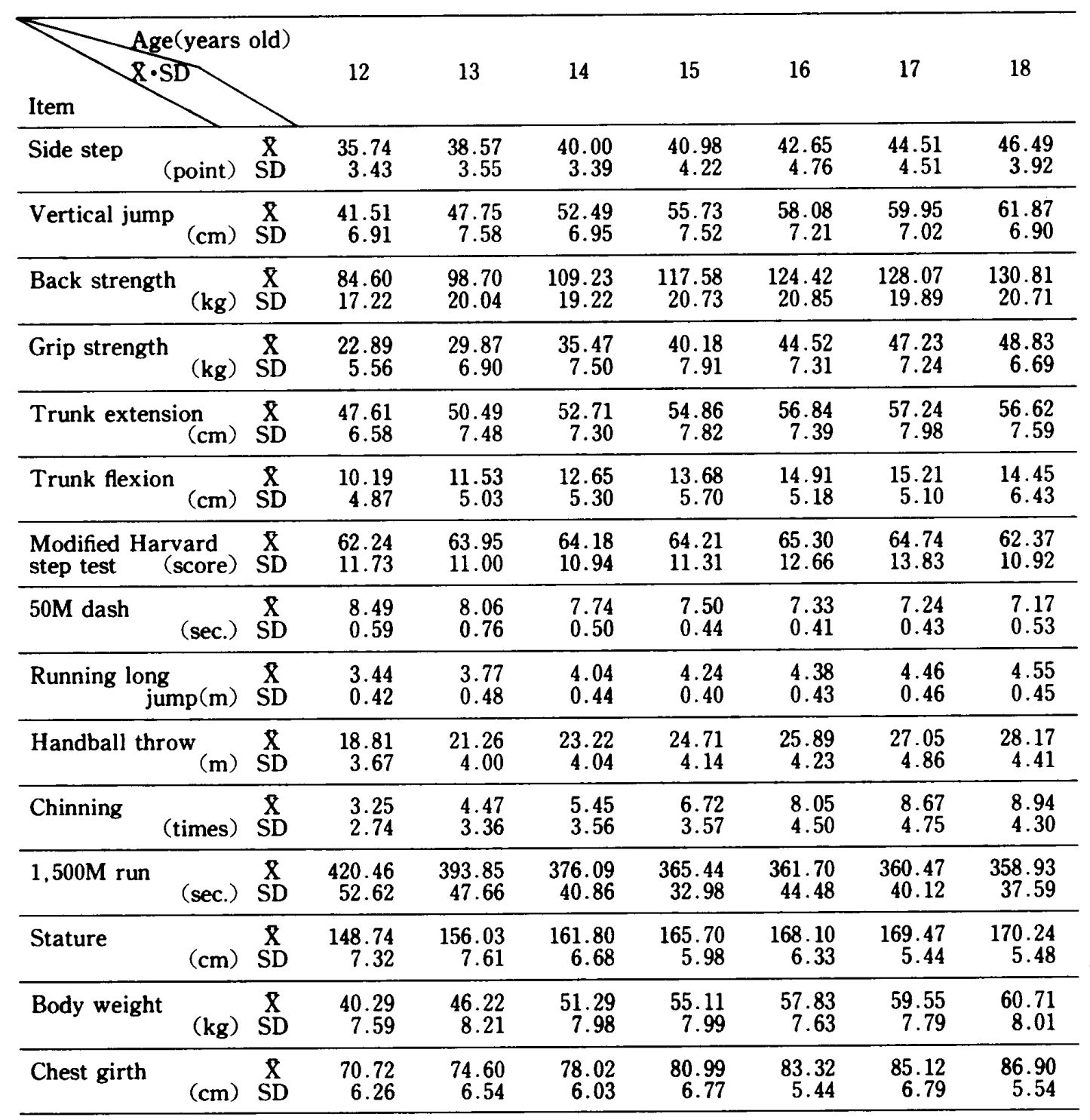

親の遗层的要因が成長と共に増加する5),11),14)身長 の発青パターンを基にして, 全体を次の 3 グルー プに分類して考察した。つまり，

（1）定增型：身長の発育バターンのチャンネル が変化しないグループ.

（2）晚熱型：身長の発育パターンのチャンネル がプラス（十）にのみ移動を示すグループ。

（3）早愁型：身長の発育バーンのチャンネル がマイナス（一）の移動を示すグループ.

であり，以上のように分類した場合 3 グループの 標本数及びその割合は，定増型 56 名， $21.79 \%$ ，晚 熟型86名, $33.46 \%$ ，早熟型115名，44.75\%であっ た。

定増型の発育曲線は，チャンネル点が変らない

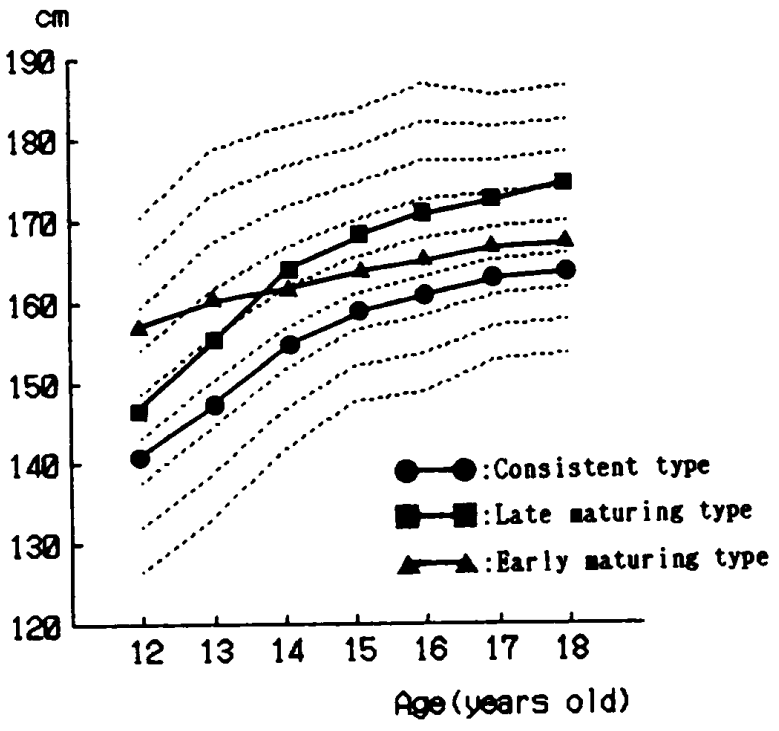

Fig. 2 Examples of consistent, late maturing and early maturing type in stature growth. 
Table 4. Growth and development pattern of each item.

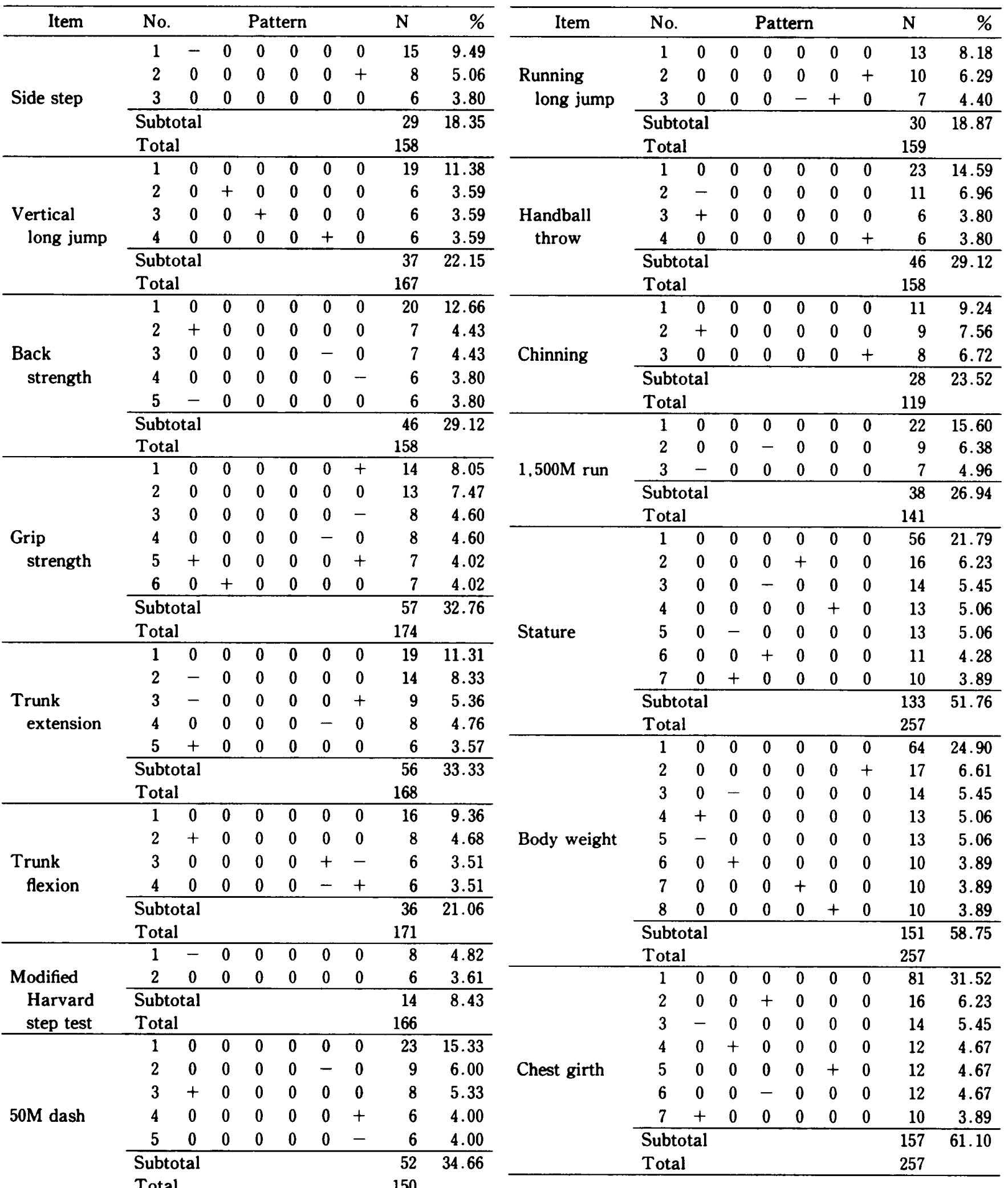

Note; (1) Total stands for number of individuals whose were measured longitudinally for 7 years, and

(2) Subtotal for sum of number of individuals belonging to the patterns whose relative frequency was greater than $3.5 \%$. 
で，平均值曲線に近い遠いはあるがほほ平行な曲 線である。晚熟型の発育曲線は，チャンネル点が 変らないか, あるいは増加のみを示す曲線であり， 中学期か高校期に発育のピークがあるものであ る。早熟型の発育曲線は，チャンネル点の減少が みられる曲線であり，発育のピークは中学期以前 にあったものと推測される，3つの型の代表例は 困 2 に示した。

身長の発育パターンの分類については，身長の

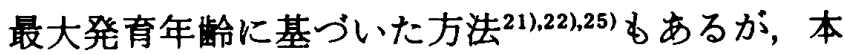
研究では他の体力要素の発達パターンの検討も

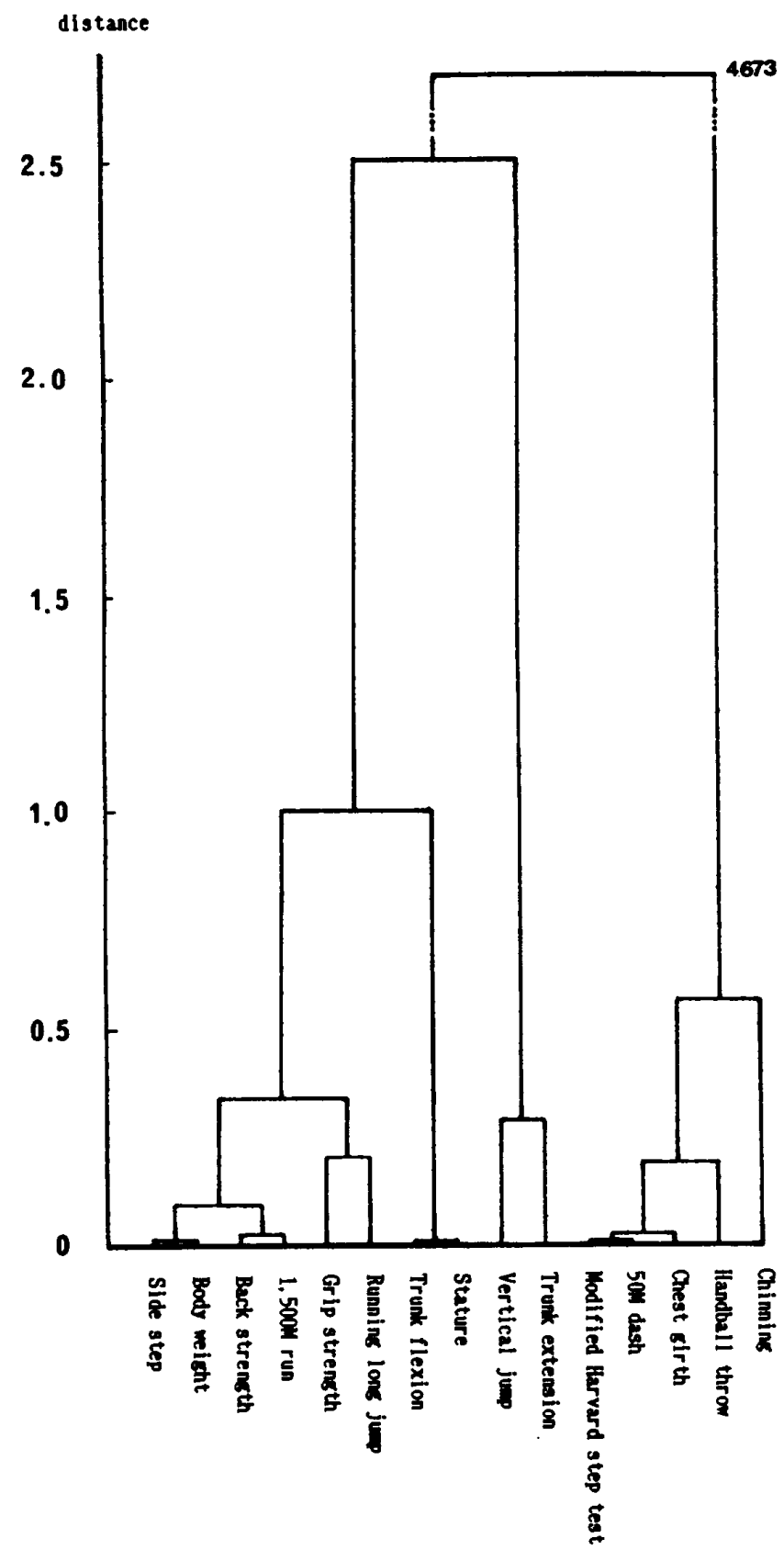

Fig. 3 Dendrogram of consistent type.
行ったことから，身長の発育パターンの分類も チャンネル法を用いた。

（2）身長発商曲緗パターン別体力要来の発连パ

\section{ターンの分類}

身長発育曲線パターンにより分類された 3 ク ループについて，それぞれの発育発達パターンを 検討するわけであるが，まず各グループの15項目 間の発育発達パターンの差異（距離）を, 先に述 ベた $\mathrm{t}$ 值により求め, 表 5 に示した。

この $\mathrm{t}$ 行列を資料として，発育発達バターンの 階思的クラスター分析(セントロイド法)总を行っ た。 その結果, 各グループのデンドログラムは図 3，図 4 ，図 5 に示す通りであり，このデンドロ グラムから距離1.0で各グループの項目を分類し たものは表 6 の通りである。つまり, 定増型では

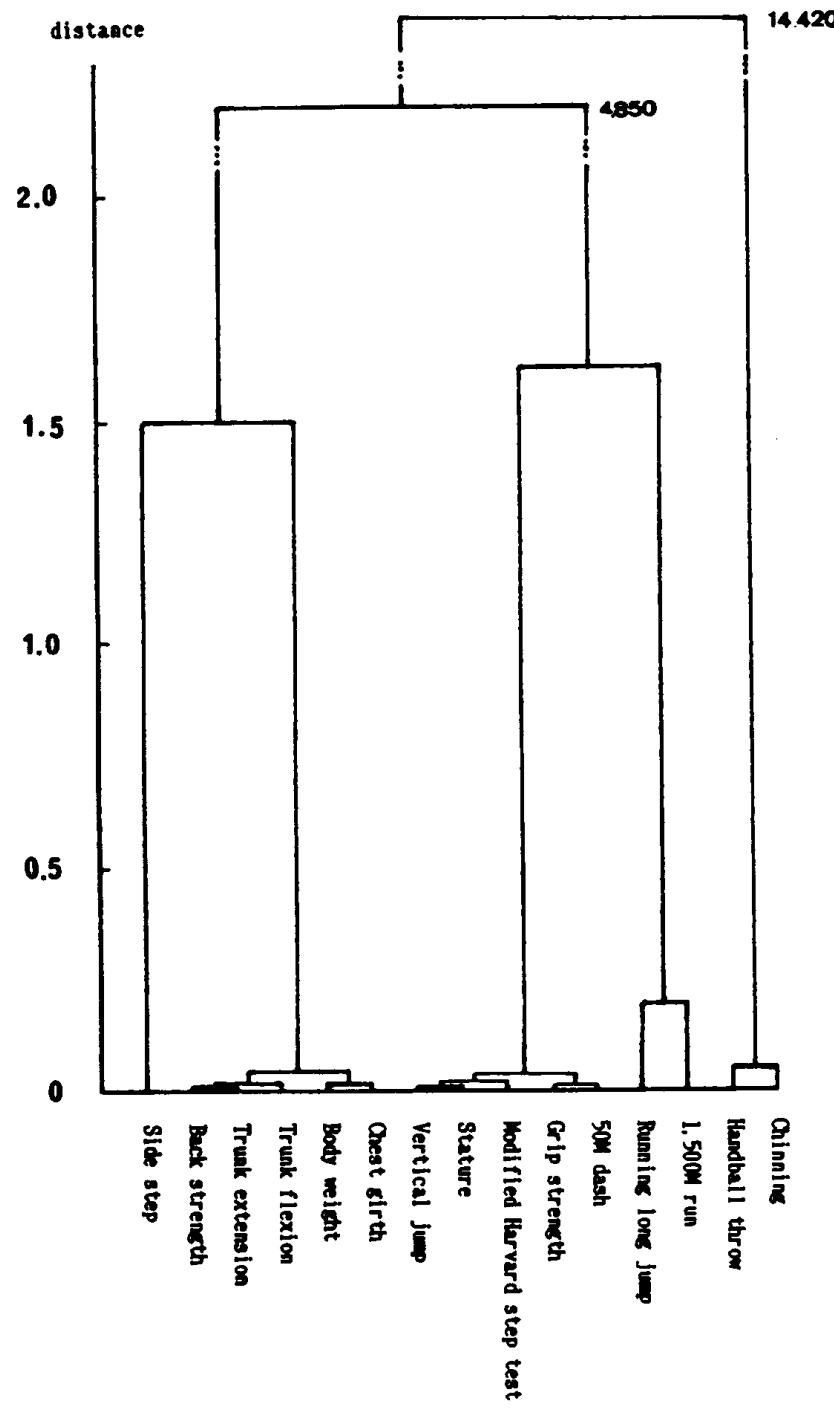

Fig. 4 Dendrogram of late maturing type. 
Table 5. T-values for testing mean differences between 15 items in consistent, late maturing and early maturing types. ( $t$-matrix, $t \times 100)$

Consistent type

\begin{tabular}{crrrrrrrrrrrrrr}
\hline Item \Item & 1 & 2 & 3 & 4 & 5 & 6 & 7 & 8 & 9 & 10 & 11 & 12 & 13 & 14 \\
\hline 2 & 180 & & & & & & & & & & & & & \\
3 & 28 & 96 & & & & & & & & & & & \\
4 & 71 & 187 & 77 & & & & & & & & & & \\
5 & 257 & 54 & 141 & 235 & & & & & & & & & \\
6 & 125 & 80 & 46 & 145 & 149 & & & & & & & & \\
7 & 218 & 353 & 154 & 54 & 443 & 343 & & & & & & & \\
8 & 170 & 300 & 140 & 50 & 370 & 270 & 1 & & & & & & \\
9 & 43 & 211 & 54 & 45 & 288 & 163 & 168 & 132 & & & & & \\
10 & 226 & 347 & 176 & 85 & 420 & 325 & 54 & 47 & 186 & & & & \\
11 & 180 & 265 & 173 & 110 & 301 & 235 & 89 & 85 & 160 & 58 & & & \\
12 & 41 & 70 & 14 & 84 & 108 & 23 & 149 & 138 & 63 & 170 & 173 & & & \\
13 & 113 & 64 & 48 & 141 & 123 & 8 & 229 & 245 & 146 & 294 & 230 & 27 & & \\
14 & 10 & 140 & 19 & 70 & 198 & 85 & 171 & 147 & 42 & 191 & 173 & 32 & 83 & \\
15 & 182 & 307 & 149 & 60 & 375 & 278 & 16 & 15 & 145 & 30 & 75 & 147 & 254 & 157 \\
\hline Late maturing & & & & & & & & & & & & & & \\
Item $\backslash$ Item & 1 & 2 & 3 & 4 & 5 & 6 & 7 & 8 & 9 & 10 & 11 & 12 & 13 & 14 \\
\hline 2 & 241 & & & & & & & & & & & & & \\
3 & 118 & 107 & & & & & & & & & & & & \\
4 & 318 & 59 & 169 & & & & & & & & & & & \\
5 & 131 & 111 & 5 & 178 & & & & & & & & & & \\
6 & 179 & 104 & 29 & 188 & 26 & & & & & & & & & \\
7 & 230 & 35 & 85 & 104 & 87 & 77 & & & & & & & & \\
8 & 292 & 31 & 144 & 31 & 151 & 155 & 73 & & & & & & & \\
9 & 406 & 116 & 258 & 115 & 274 & 299 & 214 & 144 & & & & & & \\
10 & 500 & 248 & 341 & 208 & 365 & 412 & 314 & 240 & 83 & & & & & \\
11 & 616 & 339 & 429 & 310 & 468 & 567 & 435 & 347 & 160 & 70 & & & & \\
12 & 409 & 107 & 226 & 44 & 247 & 295 & 174 & 82 & 97 & 213 & 360 & & & \\
13 & 289 & 6 & 129 & 66 & 136 & 140 & 49 & 32 & 188 & 297 & 436 & 140 & & \\
14 & 118 & 170 & 29 & 262 & 37 & 81 & 151 & 230 & 369 & 489 & 662 & 396 & 226 & \\
15 & 65 & 177 & 57 & 249 & 66 & 103 & 159 & 223 & 341 & 433 & 543 & 329 & 214 & 41 \\
\hline 5 & & & & & & & & & & & & & \\
\hline
\end{tabular}

Early maturing

\begin{tabular}{crrrrrrrrrrrrrr} 
Item $\backslash$ Item & \multicolumn{1}{c}{1} & \multicolumn{1}{c}{2} & \multicolumn{1}{c}{3} & 4 & 5 & 6 & 7 & 8 & 9 & 10 & 11 & 12 & 13 & 14 \\
\hline 2 & 102 & & & & & & & & & & & & & \\
3 & 101 & 14 & & & & & & & & & & & & \\
4 & 310 & 178 & 242 & & & & & & & & & & & \\
5 & 51 & 70 & 67 & 351 & & & & & & & & & & \\
6 & 245 & 112 & 161 & 118 & 263 & & & & & & & & & \\
7 & 285 & 170 & 215 & 23 & 296 & 105 & & & & & & & & \\
8 & 413 & 287 & 368 & 188 & 477 & 293 & 121 & & & & & & & \\
9 & 349 & 238 & 291 & 123 & 371 & 201 & 85 & 19 & & & & & & \\
10 & 383 & 273 & 330 & 171 & 411 & 248 & 126 & 28 & 40 & & & & & \\
11 & 388 & 265 & 336 & 155 & 436 & 251 & 100 & 18 & 3 & 42 & & & & \\
12 & 136 & 20 & 40 & 198 & 110 & 115 & 179 & 329 & 257 & 297 & 299 & & & \\
13 & 33 & 154 & 167 & 481 & 108 & 393 & 396 & 596 & 467 & 505 & 549 & 213 & & \\
14 & 56 & 157 & 164 & 381 & 116 & 316 & 346 & 480 & 409 & 441 & 453 & 199 & 33 & \\
15 & 11 & 90 & 88 & 293 & 37 & 229 & 271 & 396 & 335 & 368 & 371 & 123 & 46 & 67 \\
\hline
\end{tabular}

Note ; 1 : Side step, $2:$ Vertical jump, $3:$ Back strength, $4:$ Grip strength, $5:$ Trunk extension, 6 : Trunk flexion, $7:$ Modified Harvard step test, $8: 50 \mathrm{M}$ dash, $9:$ Running long jump, $10:$ Handball throw, $11:$ Chinning, $12: 1,500 \mathrm{M}$ run, $13:$ Stature, $14:$ Body weight, $15:$ Chest girth. 


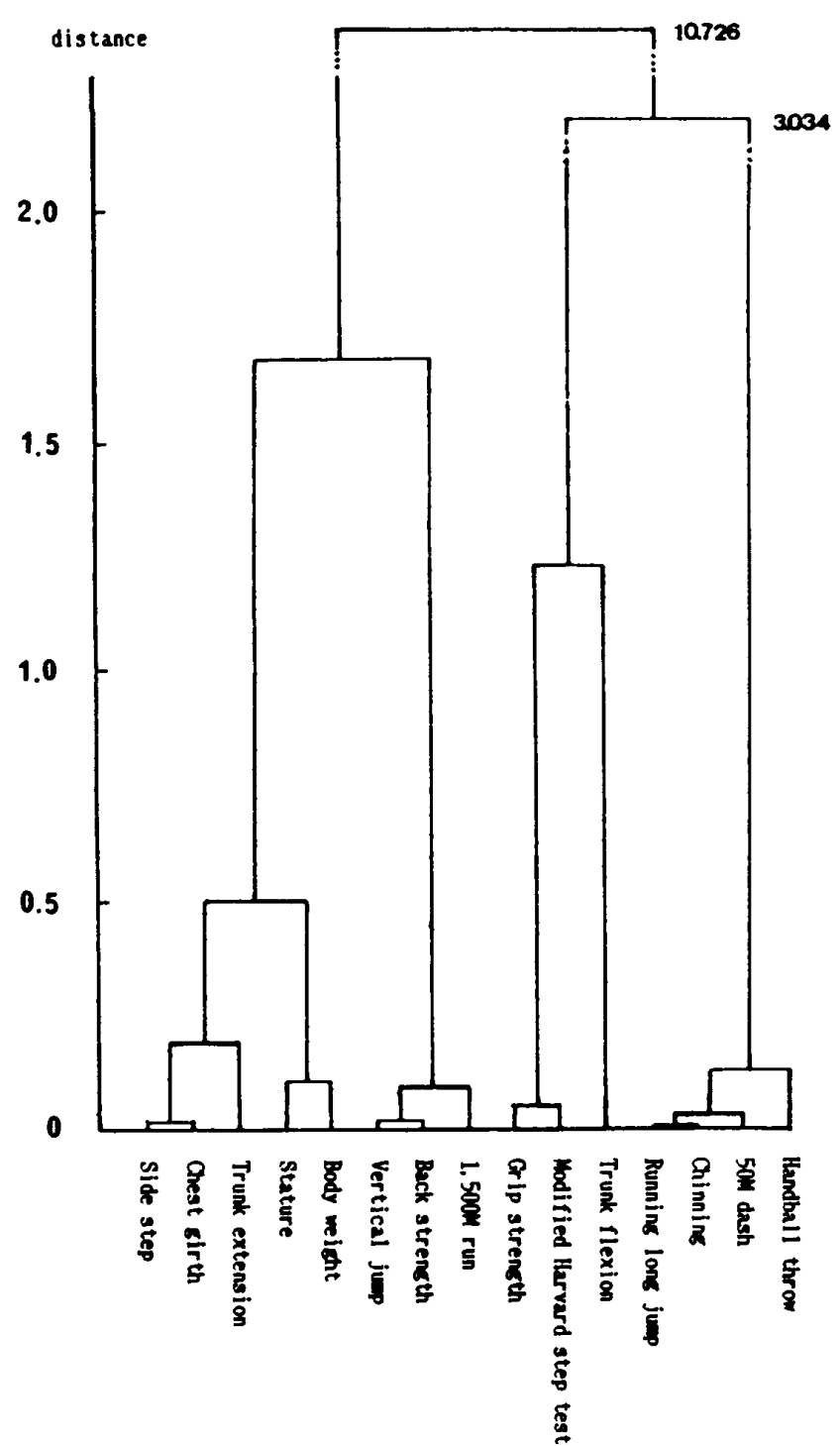

Fig. 5 Dendrogram of early maturing type.

反復横跳, 体重, 背筋力, $1,500 \mathrm{~m}$ 走, 暒力, 走り 幅跳が同じクラスターを，立位体前屈，身長が同 一クラスターを，垂直跳，伏卧上体反らしが同一 クラスターを，踏台昇降， $50 \mathrm{~m}$ 走，胸囲，ハンド ボール投げ，䈍垂がそれぞれ同一クラスターを構 成し，4つのクラスターに分類された。晚熟型で は反復横跳が単独クラスター, 背筋力, 伏臥上体 反らし, 立位体前屈, 体重, 胸囲が同一クラスター, 垂直跳，身長，踏台昇降，握力， $50 \mathrm{~m}$ 走が同一ク ラスター，走り幅跳， $1,500 \mathrm{~m}$ 走が同一クラス ター, ハンドボール投げ，惩垂がそれぞれ同一ク ラスターを構成し，5つのクラスターに分類され た。早熟型は反復横跳, 胸囲, 伏卧上体反らし, 身長, 体重が同一クラスター, 垂直跳, 背筋力,
Table 6. The classification of items resulted from cluster analysis procedure in consistent, late maturing and early maturing type.

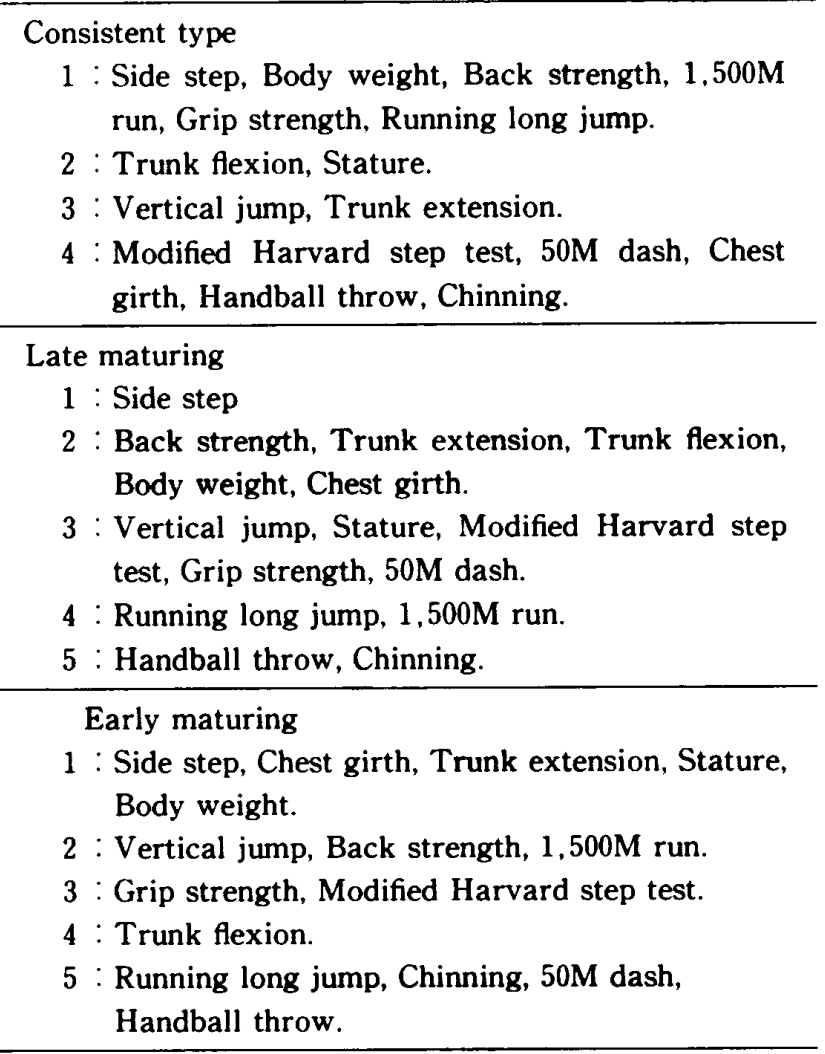

$1,500 \mathrm{~m}$ 走が同一クラスター, 握力, 踏台昇降が同 一クラスター, 立位体前屈が単独クラスタ一, 走 り幅跳，懸垂，50m 走，ハンドボール投げがそれ ぞれ同一クラスターを構成し，5つのクラスター に分類された。

（3）各クラスターの平均発青発逵曲線の検討 各グループごとに，同一クラスターに分類され た項目のチャンネル点を, 標準得点 ( $\mathrm{H}$ 得点) に 換算し，その平均値を用いて各々のグループの各 クラスターの発育発達曲線を描いた。

定増型の発育発達曲線は, 図 6(図 6-1 から図 6-4) に示寸通りである。困 6-1 は反復横跳, 体重, 背筋力, $1,500 \mathrm{~m}$ 走, 握力, 走り幅跳, 困 6 - 2 は立位体前屈, 身長, 因 6-3 は垂直跳, 伏臥 上体反らし, 図 6-4 は踏台昇降, 50m 走, 胸囲, ヘンドボール投げ，馝垂の発育発達曲線である。 図6-2, 四6-3, 四6-4 は14歳から16歳にかけ てゆるやかな凹型を示しているが，定増型の発育 発達曲線はゆるやかな上昇曲線である。中でも， 


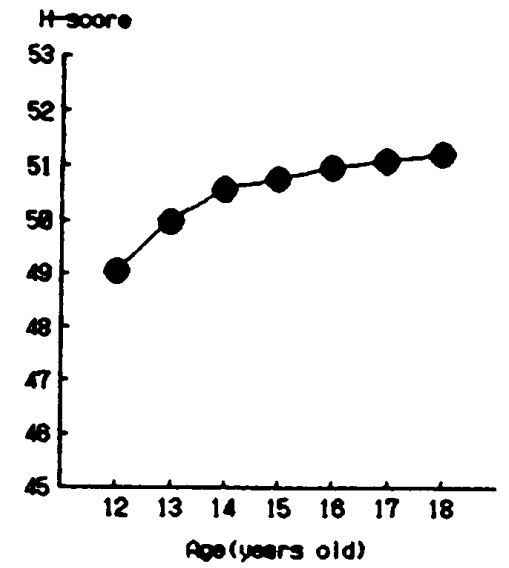

Fig. 8-1 Corsistent type 1: Side step, Body woight.8ack strength. 1.seen run.Grip strenoth. Pumning lono june.

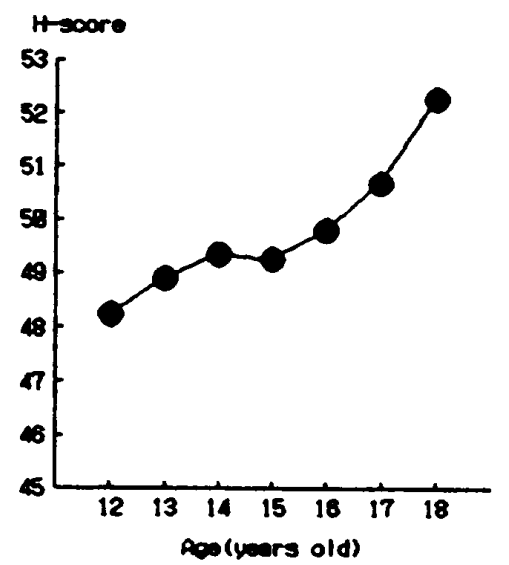

Fig. 6-2 Consistent tyoo 2; Trunk Plexion. Stature.

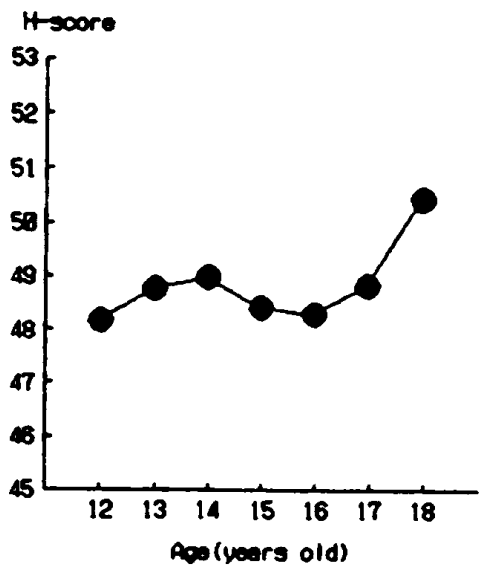

Fig. 6-3 Consistent typo 3: Uortical jump. Trunk extension.

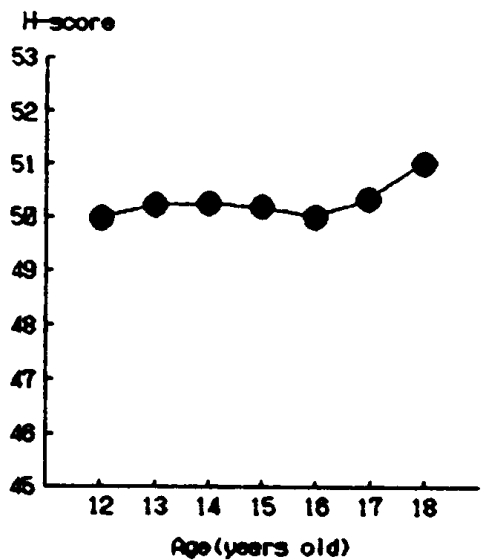

Fig. 6-4 Consistem typo 4: nodified hervard step test. sein desh. Cheer girth. Chimino. Hondbell throw.

Fig. 6 Growth and development patterns in consistent type.

図 6-2 が示すように身長，立位体前屈は，他より 急勾配の上昇曲線である。

晚熟型の発青発達曲線は, 図 7 (図 7-1 から図 7-5）に示す通りである。因 7-1 は反復横跳, 図 7-2 は背筋力, 伏臥上体反らし，立位体前屈， 体重, 胸囲, 図 7-3 は垂直跳, 身長, 踏台昇降, 握力, $50 \mathrm{~m}$ 走, 図 7-4 は走り幅跳, $1,500 \mathrm{~m}$ 走, 因 7-5はハンドボール投げ, 惩垂の発育発達曲線 である．定増型の曲線より勾配が急な上昇曲線で あり, 図 7-2, 図 7-3, 図 7-5 が示す背筋力, 伏臥上体反らし, 立位体前屈, 体重, 胸囲, 垂直 跳, 身長, 踏台昇降, 握力, $50 \mathrm{~m}$ 走, ハンドボー ル投げ，愻垂の12項目の発育発達曲線は急勾配上 昇曲線である。

早热型の発育発達曲線は，図8（図8-1 から困 8-5）に示す通りである。因 8-1 は反復横跳, 胸囲, 伏臥上体反らし, 身長, 体重, 困 8-2 は垂
直跳, 背筋力, $1,500 \mathrm{~m}$ 走, 困 $8-3$ は握力, 踏台 昇降, 図 8-4 は立位体前屈, 図 8-5 は走り幅跳, 悡垂, $50 \mathrm{~m}$ 走，ハンドボール投げの発育発達曲線 である，定増型，晚㷫型の発育発達曲線とは逆の 下降曲線であり，その型は一様ではない。

定増型では, 図 6-1の発育発達曲線を示するの は表 6 が示す通り，反復横跳，体重，背筋力， 1,500 $\mathrm{m}$ 走, 握力, 走り幅跳であり,これら6 項目は同 一クラスターに分類されていることから類似した 発育発達パターンを示すと考えられる．晚热型で 定增型の図 6-1 と類似した発育発達曲楾を示し ているのは, 図 7-1 が示す反復横跳の発達曲線で ある、また，䈍垂とハンドボール投げは，表 6 が 示す通り各クループで同一クラスターに分類され ているが，図 6-4，図 7-5, 図 8-5が示す通り その発達曲線は類似していない，このように，身 長の発育パターンが異なるグループでは, 同一の 


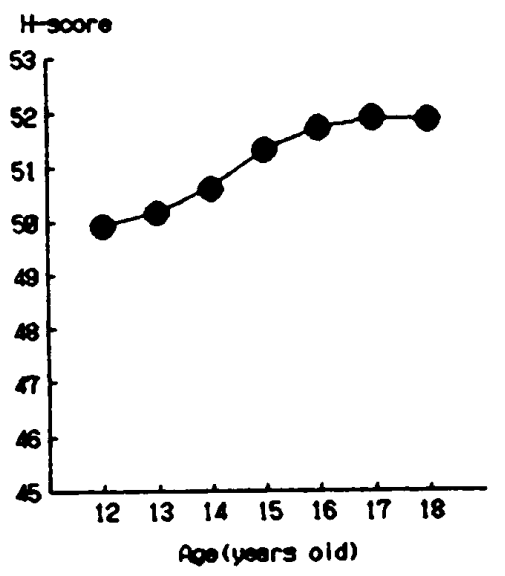

Fig. 7-1 Lote maturing typo 1:Side step.

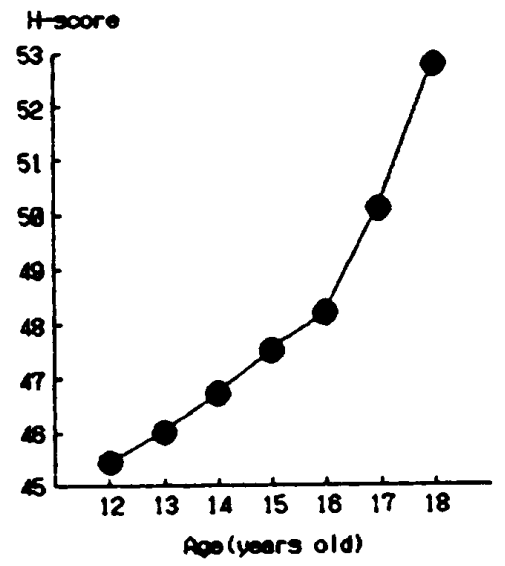

Fig. 7-2 Late maturino type 2; Beck strenoth.Body woioht.

Trunk extension. Trunk flexion. Cheost girth.

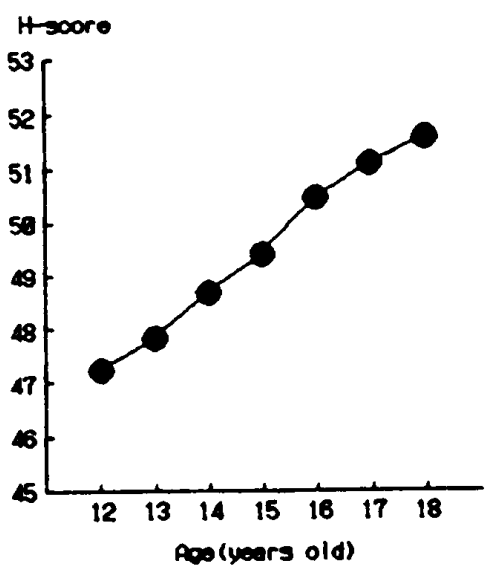

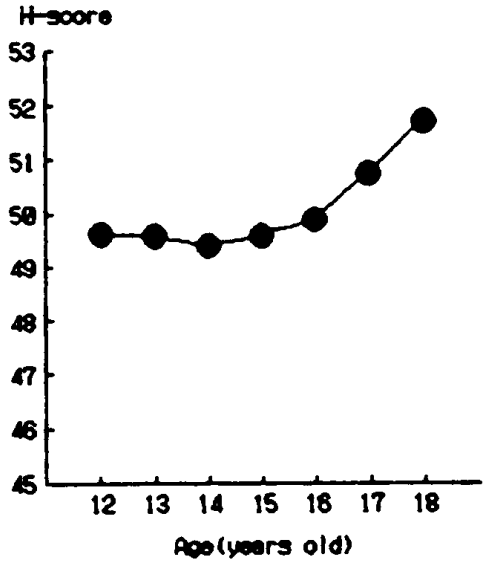

Fig. 7-4 late moturing type 4:Rumino long juep. 1.56in run.

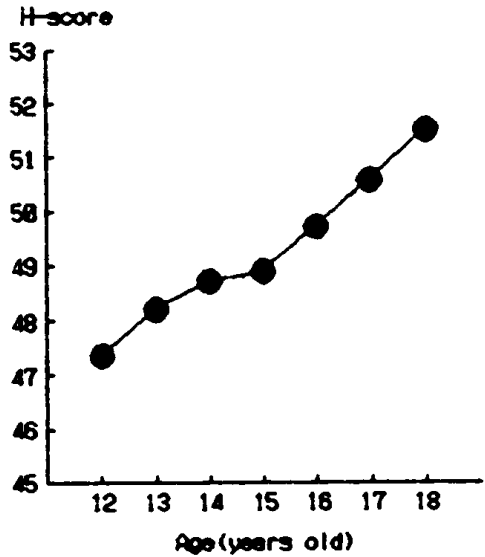

Fig. 7-5 Late maturino type 5:Kendbell throw.Chinino.

Fig. 7-3 late moturing type 3:Vertical jum. Stature.

Modified Horverd step teot.Grip strength.5en desh.

Fig. 7 Growth and development patterns in late maturing type.

発育発達パターンを示す能力要素は異なると同時 に，同じ能力要素でも発育発達バターンは異なる ことが示唆された。

反復横跳は定増型グループでは図 6-1の定増 型 1 のパターンを示し, 体重, 背筋力, $1,500 \mathrm{~m}$ 走, 握力, 走り幅跳も同様なパターンを示すと推測さ
れたが, 晚熟型では反復横跳のみが図 7-1の晚熟 型 1 のパターンを示し, 定増型 1 のパターンを示 した反復横跳以外の項目とは異なったパターンを 示していると考えられた。しかし，晚熱型では背 筋力, 体重は図 7-2 の晚熟型 2 を示し, 反復横跳 より発達の加龄にともなら加速がより顕著である 


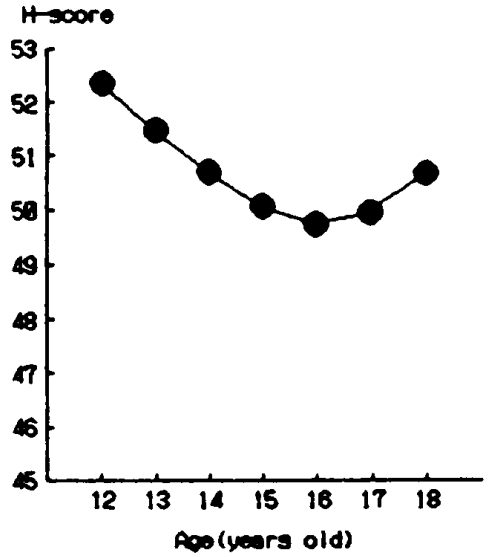

Fig. ofl Early maturing typo 1: Side step.Chest girth.

Trunk extersion. Stature. Body wioldt.

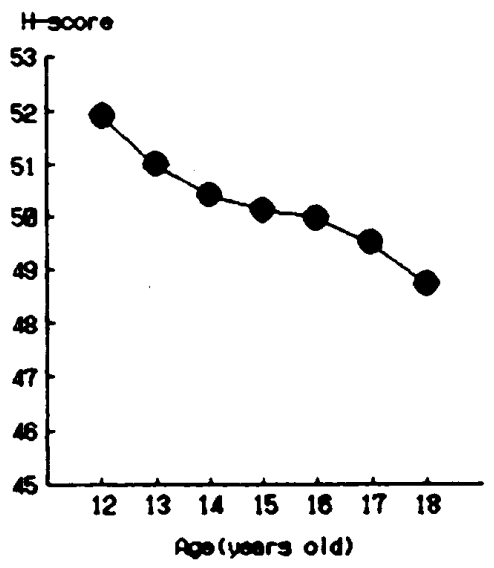

Fig. 8-2 Early aturing type 2:Uertical jump.Back strenoth. 1.580 run.

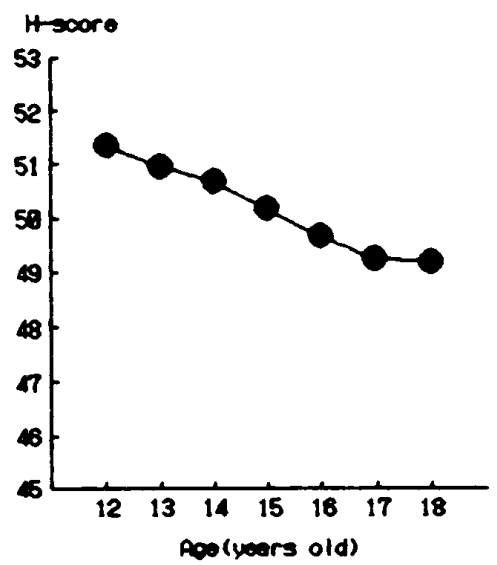

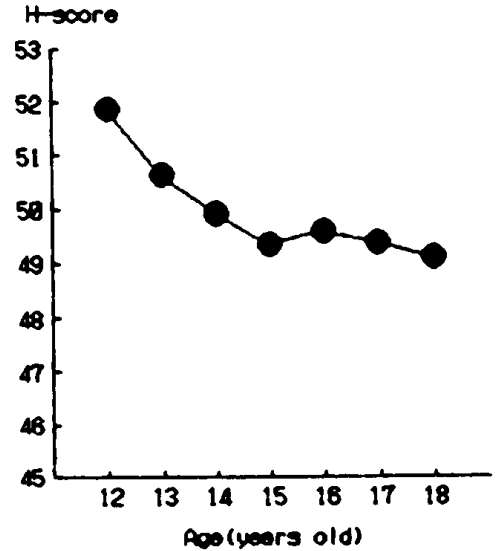

Fig. 8-4 Early moturing typo 4: Trunk flexion.

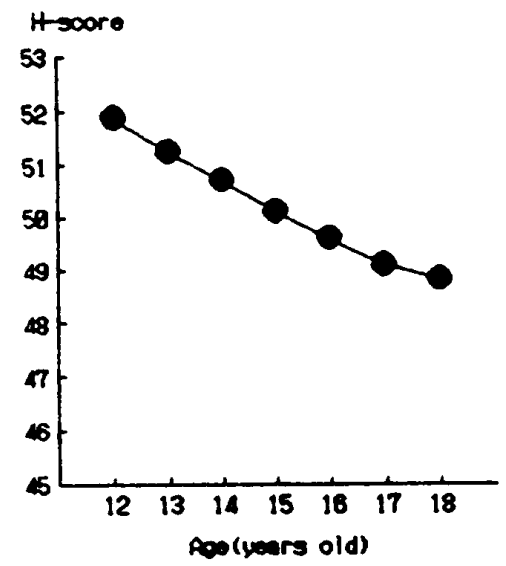

Fig. o-5 Early maturino tyo 5: Pumino lono jumo.Chiming. ser desh. Hendbell throw.

Fio. 8-3 Early moturing type 3:Grip strencth.

Modified Herverd step teot.

Fig. 8 Growth and development patterns in early maturing type.

ことが図 7-2 からわかる.また, 走り幅跳, 1,500 $\mathrm{m}$ 走は図 7-4の晚就型 4 に, 握力は図 7-3 の晚 热型 3 を示し，これらの諸項目は晚热型 1 より発 達の加速がより12歳以降か又は，14～15葴項より 顕著になっており，この発達の加速が顕著になる 時期の差異によって，定増型 1 として同様なパ
ターンを示したこれらの項目が，晚熟型では4つ のバターンに分類されていると考えられた。これ に対し，早熟型では図 8 が示すように，チャンネ ル点の低下を示すバターンが多いが, 図 8-1の早 熟型 1 を示す反復横跳は再びチャンネル点の増加 を示すパターンを身長，胸囲，体重，伏臥上体反 
らしと共に示していた。これは，定増型，晚熟型 ともにこれらの諸項目の向上傾向の加速が見られ る時期に相当している. しかし，定増型，晚熟型 では早熟型でチャンネル点の減少が見られる時期 には，チャンネル点の减少は見られず，定常か又 は増加㑯向を示している。

3 群間における発育発達傾向は同じパターンを 示すことはなく，しかも類似していると推測され るパターンに属する項目は，3群間でまた異って いた。これらの差異は, 定増型と晚熟型との間で は発育発達の加速の時期の差によるすのと推測さ れる。早熟型では，すでに発育発達の加速はここ でとりあげた年龄段階では終っていると推測さ れ，チャンネル点の减少がその主な特徵であり， その减少傾向の程度及びその程度の変化の時期の 差異がこれらのハターンの分類の主たる原因と なっていると推測された。

小宮8)は，10歳から14歳までの少年期の身長の 発育ハターンを上昇型, 下降型, 凸型, 凹型, 混 合型に分類している，そして，10歳から14歳まで の少年期における望ましい身長の発育パターンは 凸型であり，下降型と凸型は運動能力がすぐれて いると報告している。ここで述べられている下降 型, 凸型は本研究では早熟型であり, 発育発達曲 線は下降曲線である。

吳・松浦 ${ }^{20}$ は, 身長発育の加速時期の早いものの 最大発育量はこの時期の遅いものの最大発育量よ り大であるが, 以後の発育量の減少傾向は急激で あると報告している。本研究の早熟型の下降曲線 も同様の減少傾向と考兄られる.

服部1)は，思春期後の形態は相対的な変動が安 定してくると報告している. 本研究の 3 グループ の発育発達曲線は思春期後の安定へ向けて, 定増 型はゆっくり上昇, 晚熟型は急上昇, 早熟型はさ まざまな型の下降といら発育発達パターンを辿っ ていると推測される。

\section{ま と め}

身長の発育パターン別に, 12 歳から18歳までの 青少年男子体力の発達パターンを比較検討した結 果, 次のよ5な結論が得られた。
（1）身長の発育バターンはチャンネル法により 分類すると，チャンネル変化のない定増型 (21.79\%),チャンネルがプラスにのみ移動を示す 晚熟型 (33.46\%)，チャンネルがマイナスに移動 する早熟型 (44.75\%) であった。

（2）各グループの15項目間の発育発達パターン の差異 (距離)を $\mathrm{t}$ 值により求め, $\mathrm{t}$ 行列を資料と して階層的クラスター分析を行った。 その結果, 定増型は 4 つのクラスター, 晚熟型, 早熟型はそ れぞれ 5 つのラスターに分類された。

（3）各グループごとに，同一クラスターに分類 された項目のチャンネル点を標準得点 ( $\mathrm{H}$ 得点) に換算し，その平均値を用いて各々のグループの 発育発達曲線を描いた，定増型はゆるやかな上昇 曲線，晚熟型はいくぶん急勾配の上昇曲線，早熟 型はさまざまな型の下降曲線を示した。

（4）身長の発育パターンが異なるグループで は, 同一の発育発達パターンを示す能力要素は異 なると同時に, 同じ能力要素でも発育発達パター ンは異なっていた。

注

注 1 ）槚本は 5 つのコーホート（cohort）から構成さ れている。つまり，1969年入学生。1970年入学生, 1971年入学生, 1972年入学生, 1973年入学生である. これらについて1969年度は1969年入学生の中学 1 年 時を湖定した。次年度は1969年入学生の中学 2 年時 及び1970年入学生の中学 1 年時を測定した。さらに 次年度は1969年入学生が中学 3 年時, 1970年入学生 が中学 2 年時及び 1971 年入学生が中学 1 年時につい て測定した。したかってて各個人の測定は全てのコ一 ホートについて7回測定したことになり, 全測定自 体は1969年より1979年までの11回行われた。

注 2 ) 標準得点とはいわゆる偏差値のことで, 各々単 位の異なる項目を正規分布を仮定することにより同 一の尺度に変换した得点のことである。この得点に は $Z$ 得点, $T$ 得点, $C$ 得点があり, $H$ 得点もこの 1 種である. $\mathrm{H}$ 得点を求める式は本文中に示した。

\section{引用・参考文献}

1) 服部恒明「思春期後の発育の綎断的分析」体育学研究, $18-4: 185-90,1974$.

2）保志宏「発育曲線を読み直す」自然，3:64-73, 1977 .

3）市村操一「発達曲線の分類法について一主成分分析法 
とクラスター・アナリシスの道用の比慗一」東京教育大 学体育学部紀要, $12: 29-32,1973$.

4) 岩原信九郎, 新訂版, 教育と心理のための推計学, 日 本文化科学社, 1965. pp. 181-82.

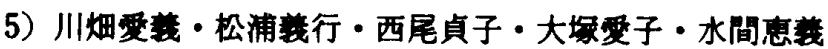
子「発育・発逵を制的する諸因子の分析一第 1 報一形態

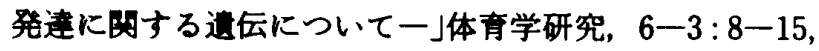
1962.

6）木田信子・坂元佐多子・細川涼一・勝木新次「緃断的

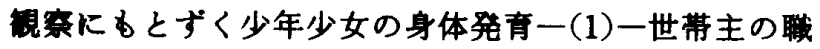
莱と少年少女の身体発育一」体力研究，2:3-28, 1964.

7）木村邦彦「身長と体重の相対成長からみた個成長の変

異」東京教育大学体育学部紀要, 9:77-88, 1970.

8）小宫秀一「少年期における身長の発育 Pattern と運動 能力の発逞について」体育学研究, 16-2:75-84, 1971.

9）小宮秀一「身長の発育 PATTERN 別にみた形態発育 の特性について一相対成脣による分析一」体育学研究, 19-2: 99-106, 1974.

10）小宮垩一・大坂哲郎「身長一体重の相対成長による男 子児童（6才〜14才）の発青ハターンについて」体育学 研究, 20-2:79-89, 1975.

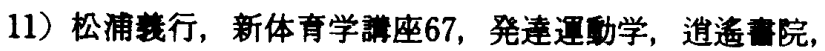
1975. pp. 9-33.

12）松浦義行・中村栄太郎「基磁通功能力の発達に㘣する 研究一4 8藏の男子について一」体育学研究, $21-5: 293$ $-303,1977$.

13) Matsuura, Y., "Study on the growth and development path pattern with short range longitudinal data physical fitness," 第35回日本体力医学会大会予稿集： $163,1980$.

14）松浦意行, 現代の体育・スボーッ科学, 体力の発達, 朝合晋店, 1982. pp. $71-76$.

15）松浦美行, 現代の体育・スボーッ科学, 体育・スボー ッ科学のための就計学, 朝合晋店, 1985. pp. 38-42.

16）松浦義行「体力梳計からみた青少年の体力」小児科 Mook, 29: 11-27, 1983.

17）松浦䣡行,「体育科学における多变量統計解析手法によ る研究の動向」広田公一・浅見俊雄（編），人間と身体運 䡃, 杏林院, 1984. pp. 183-90.

18）森下はるみ「相対発育よりみた成热の研究一個体にお
ける発育曲線の変移について一」体育学研究, 8-3.4:93 -99, 1965.

19）森下はるみ「秏幼児における身長一体重相対発育」体 育学研究, 13-3:189-94, 1969.

20）吳 莴元・松浦域行「韩国青少年の身体的発育発達に 间する綎断的研究一Adolescent Spurt における発青速 度に闺する考察一」日本体育学会第32回大会号：508, 1981.

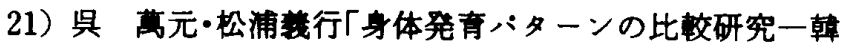
国・日本・英国一」日本体育学会第34回大会号：459, 1983.

22）太田和䇅・藤井勝紀「身体の発育ハターンの分析的研 究」日本体育学会第35回大会号：503，1984.

23）奥野忠一・久米 均・考号敏郎 - 吉澤 正, 多变五解 析法，日科技連，1971. pp. 391-406.

24）洼水三雄「呪童・生徒期における上肢長の下肢長に対 する綎断的相対成長」解剖学雑誌，40-2:92-100, 1965.

25）高石昌弘「児童・生徒の発䏍とその問題」小児医学, 4-1:13-41, 1971.

26）高石昌弘「身体発育の年次的推移」日本公俉誌，22-10 : 563-69, 1975.

27）高石昌弘・大森世都子・江口笏寿・藤田良子「思春期 身体発育のパターンに因する研究一第 1 報一男子の身長 発育速度および体重発育速度について一」小児保健研究, $26-2: 57-63,1968$.

28）高石昌弘・大森世都子・宮部黎子・岩本幸弓「思春期 身体発育のパーンに荓する研究一第 2 報一女子の身長 発育速度，体重発育速度および初潮年峆について一」小 児保健研究，26-6:280-85, 1969.

29）高石昌弘・大森世都子「思春期身体発育のバターンに 间寸る研究一第 3 報一身長発育速度曲線のバターン, 特 に，思春期急增の闰始と発育終了の年龄について一」小 児保健研究, 29-6:259-63, 1971.

30）寺田春水・保志去「個人追跡法による日本人の発充 の研究一(2)一生後 3 年間の身長と体重の変化一」解剖学 雑誌, 40-3:166-77, 1965.

31）寺田春水・保志 宏「個人追跡法による日本人の発育 の研究一(3) 一生後 3 年間の胸囲と頭囲の変化一」解剖学 雑誌，40-6:368-80, 1965.

32）東京都立大学身体適性学研究室, 日本人の体力標準值, 第二版，不昧堂出版，1975. pp. 24-30. 